\title{
Assessment Standardization of Music Art Work in Music Education Study Program FBS Universitas Negeri Medan
}

\author{
${ }^{1}$ Uyuni Widiastuti \\ \{yuniyhundai@gmail.com\} \\ ${ }^{1}$ Prodi Pendidikan Musik Universitas Negeri Medan, Indonesia
}

\begin{abstract}
The competency assessment of Music Education Study Program is called the Music Art Work presentation which is conducted individually and in group. The competency assessment is conducted in the form of a musical instrument practice test chosen by students as a major instrument in the Music Education Study Program. It is as the presentation of a single musical work and teaching music practice material for the high school students as a group music presentation. Both music art work presentation forms have to follow the assessment provided by the Music Education Study Program in order that the assessment was conducted based on the standards of the Music Education Study Program at FBS Unniversitas Negeri Medan for all the students.
\end{abstract}

Keywords: Standardization, Competency assessment, Music Art

\section{Introduction}

Sendratasik Department of Language and Arts Faculty consists of three study programs namely Music Education Study Program, Dance Education Study Program, and Performing Arts Study Program. These three study programs have practical courses that must be taken by all students to support their competencies as music teachers, dance teachers or dance / music artists. The arts competences must have clear assessment standards. Therefore, there will be same standards for anyone who assesses and is judged to have the same assessment standards. The competency assessment in the arts must refer to graduate profiles and the resulting competencies to support graduate profiles.

Music Education Study Program is a study program that has a profile of primary graduates as music teachers / educators, while supporting graduate profiles are practitioners of art (artists) and entrepreneurs in the field of music. Students said to be worthy of competence in the field of music must take the music art competency test conducted by Music Education Study Program. Music art competency test is assessed by lecturers who take practical subjects by following the assessment format provided. Therefore, if the students graduated, the students will have a graduation certificate of music competency.

In general, competence is the authority and person ability to carry out tasks or jobs in accordance with the position borne. Competence is an ability to carry out or do a job or task based on skills and knowledge and was supported by the work attitude demanded by the job [1]. The 
objectives of the study were to achieve the competence concept such as behavior, skills and knowledge that were part of the emergence of one's competence.

Furthermore, when it is related to art, it can be said that art competency is a person's ability to perform arts skills and can express human feelings that have an element of beauty in them and expressed through a media that is real, be it in the form of tone, form, motion, and poetry, which can be felt by the five human senses.

Music art is a branch of art that discusses and assigns various sounds into patterns that can be understood by humans. Music art was the expression of the sense of beauty of a human being manifested in tones or sounds that ultimately produce rhythm and harmony [2]. Music will sound beautiful because of various musical elements incorporated in it. The elements contained in the art of music are as follows:

A melody is an arrangement of notes (sounds in regular order) that sound sequentially and rhythmically and express an idea of thoughts and feelings [3]. A melody consists of duration, pitch, and tone. Pitch is a matter that regulates a series of notes with the A-G alphabet symbol. Pitch is often called timbre or sound color. The series of notes becomes a melody in a certain time series called duration. Musical notes can be produced from various musical instruments with different sound colors or referred to a tone.

Rhythm is a sequence of series of movements that form the basic elements in music and dance, rhythm in music is formed from a group of sounds and silence with various lengths of time or short lengths, forming rhythmic patterns, moving according to pulses in swinging rhythms, rhythms and can felt, sometimes felt and heard; felt and seen; or felt, heard and seen [2].

Bar is an element of musical art in the form of repeated beats / swings that come regularly at the same time. Bar is a segment that divides song sentences into the same measurements that are marked with certain symbols or numbers [2]. The bars are written in fractional numbers like $2 / 4,3 / 4,2 / 3$, and so on. An even denominator whose name is evenly called bainar bar, while an odd denominator is called ternair bar.

Harmony or chorus is a composition of several different tones of high pitch that are heard simultaneously which causes harmony of sound [3]. Harmony has interval and chord elements. An interval is an arrangement of two tones if sounded, while a chord is a combination of three or more notes that are sounded simultaneously.

Tempo is the speed of a song [4]. Tempo is associated with the speed of movement of music or song, or it can be said to be a measure of the speed of a song's bar. In general, the tempo sign is divided into 4, namely Slow Tempo (Largo), Medium Tempo (Moderato), Fast Tempo (Allegro), Tempo of Change (Rit, Ritard).

Dynamic is a sign to express the level of volume, or softness of sound and changes in the sound and softness of the sound [3]. In general, dynamic signs are divided into 3, which are as follows: Soft dynamic signs (piano), Medium dynamic signs (moderate), hard dynamic signs (forte). Dynamic is the most powerful element to show the emotions or feelings contained in a musical work when compared with other elements. Dynamic can show a work of music that has emotions or feelings such as sad, carefree, happy, aggressive, or flat. The scale is a series of notes, going up and down along an octave [4]. There are 3 types of scales, namely Diatonic Scale, Pentatonic Scale and Chromatic Scale.

Timbre is the sound color found on a musical instrument [2]. A musical instrument's timbre is influenced by the sound source and how it vibrates. The timbre produced by stringed instruments 
will certainly be different from the timbre produced from the striking instrument, even though both are played in the same vein.

\section{Discussion}

Art competency test in Music Education Study Program is called Music Art Presentation which was conducted in the form of Music Art Forum. Music Art Forum activities were carried out by representing material that has been studied from semester I to semester IV of the selected instrument courses consisting of preparatory choice instruments, basic choice instruments, intermediate choice instruments and advanced choice instruments.

Elective Instruments course consist of piano, wind instruments (saxophone, flute, trumpet), string (violin, violin, cello and contra bass), percussion (non-pitched and pitched percussion), guitar and vocals. Each musical instrument has the same material, including scale (tones and tri voices), etude and songs that are adjusted to the playing technique of each of the musical instruments.

The last material will be presented again at the Presentation of Music Art activities called the Music Arts Forum. After being presented there would be a discussion about how students present the material of the musical instrument.

The following will be presented the art competency test standards that would be used in the Presentation of Music Art (Music Art Forum). There are two types of forms of presentation of music that must be presented at the Music Arts Forum, namely:

\section{a. Single Music Forum}

The Single Music Forum aimed to assess the student's practical ability to the material that had been given in lectures from semester I to semester IV on selected musical instrument courses. Students present music artwork chosen by the lecturer to be presented in a single forum. Students are also guided by a supervisor at least five times (through a forum guidance book) and are approved to conduct a Music Arts Forum. The following will be presented in the rubric assessment format on the Music Art Presentation competency test standard through the Music Arts Forum.

\section{b. Group Music Forum}

The Group Music Forum aims to assess the students' ability in applying professional, didactic and methodical competencies in music learning toward the students in the school. The students independently or in groups must train the junior and high school / vocational high school students by teaching music practice. The materials taught is course materials that have been studied during lecturing at the Music Education Study Program, namely: Music Instrument course (wind instrument, stringed instrument, percussions instrument, stringed instrument, vocal and piano) and School Music Ensembles (orchestras, music traditional, marching band). The following is the assessment standardization of single / group music works. 
Table 1. Music Art Presentation Assessment Rubric (Single Music Art Forum)

\begin{tabular}{|c|c|c|c|c|c|c|}
\hline \multirow[t]{2}{*}{ NO } & \multirow{2}{*}{$\begin{array}{c}\text { Rated } \\
\text { Aspects }\end{array}$} & \multirow[t]{2}{*}{ Indicators } & \multicolumn{4}{|c|}{ SCORE } \\
\hline & & & $\begin{array}{c}\text { Very Good } \\
\text { (4) }\end{array}$ & $\begin{array}{c}\text { Good } \\
(3)\end{array}$ & $\begin{array}{c}\text { Enough } \\
(2)\end{array}$ & $\begin{array}{c}\text { Less Good } \\
\text { (1) }\end{array}$ \\
\hline 1 & Duration & $\begin{array}{l}\text { Tempo } \\
\text { Accuracy }\end{array}$ & $\begin{array}{l}\text { Playing / } \\
\text { singing is in } \\
\text { the right } \\
\text { tempo and } \\
\text { stable with a } \\
\text { range:Largo } \\
\text { 40-60 bpm, } \\
\text { Larghetto } \\
60-66 \text { bpm, } \\
\text { Adagio 66- } \\
76 \text { bpm, } \\
\text { Andante } 76- \\
108 \text { bpm, } \\
\text { Moderato } \\
108- \\
120 \text { bpm, } \\
\text { Allegro } \\
120-156 \\
\text { bpm, Presto } \\
168- \\
200 \text { bpm, } \\
\text { Prestissimo } \\
200-208 \\
\text { bpm in } \\
\text { accordance } \\
\text { with the } \\
\text { sheet music }\end{array}$ & $\begin{array}{l}\text { Playing / } \\
\text { singing is } \\
\text { in a stable } \\
\text { tempo but } \\
\text { not in } \\
\text { accordan } \\
\text { ce with } \\
\text { the range } \\
\text { written: } \\
\text { Largo } 40- \\
60 \text { bpm, } \\
\text { Larghetto } \\
60-66 \\
\text { bpm, } \\
\text { Adagio } \\
66- \\
76 \text { bpm, } \\
\text { Andante } \\
76- \\
108 \text { bpm, } \\
\text { Moderato } \\
108- \\
120 \text { bpm, } \\
\text { Allegro } \\
120-156 \\
\text { bpm, } \\
\text { Presto } \\
168- \\
200 \text { bpm, } \\
\text { Prestissim } \\
\text { o } 200-208 \\
\text { bpm in } \\
\text { accordanc } \\
\text { e with the } \\
\text { sheet } \\
\text { music }\end{array}$ & $\begin{array}{l}\text { Playing / singing is } \\
\text { an unstable } \\
\text { tempo but in } \\
\text { accordance with } \\
\text { the written } \\
\text { range:Largo } 40- \\
60 \text { bpm, Larghetto } \\
60-66 \text { bpm, Adagio } \\
66-76 \text { bpm, } \\
\text { Andante } 76- \\
108 \text { bpm, } \\
\text { Moderato 108- } \\
120 \text { bpm, Allegro } \\
120-156 \text { bpm, } \\
\text { Presto } 168- \\
200 \text { bpm, } \\
\text { Prestissimo } 200- \\
208 \text { bpm sesuai } \\
\text { dengan partitur } \\
\text { lagu } \\
\text { in accordance with } \\
\text { the sheet music }\end{array}$ & $\begin{array}{l}\text { Playing/ singing } \\
\text { with a tempo and } \\
\text { range are not } \\
\text { accordance with } \\
\text { the written tempo }\end{array}$ \\
\hline & & $\begin{array}{l}\text { The Bar } \\
\text { Signature } \\
\text { Accuracy }\end{array}$ & $\begin{array}{l}\text { Playing / } \\
\text { singing a } \\
\text { melody is } \\
\text { well in } \\
\text { accordance } \\
\text { to the } \\
\text { simple Bar }\end{array}$ & $\begin{array}{l}\text { Playing / } \\
\text { singing a } \\
\text { melody is } \\
\text { well, but } \\
\text { not } \\
\text { accordan } \\
\text { ce to the }\end{array}$ & $\begin{array}{l}\text { Playing / singing a } \\
\text { melody is not } \\
\text { well, but in } \\
\text { accordance to the } \\
\text { simple Bar } \\
\text { accentuation } \\
\text { pattern }(2 / 2,\end{array}$ & $\begin{array}{l}\text { Playing / singing a } \\
\text { melody is not well } \\
\text { and not } \\
\text { accordance to the } \\
\text { simple Bar } \\
\text { accentuation } \\
\text { pattern }(2 / 2,\end{array}$ \\
\hline
\end{tabular}




\begin{tabular}{|c|c|c|c|c|c|c|}
\hline \multirow[t]{2}{*}{ NO } & \multirow{2}{*}{$\begin{array}{c}\text { Rated } \\
\text { Aspects }\end{array}$} & \multirow[t]{2}{*}{ Indicators } & \multicolumn{4}{|c|}{ SCORE } \\
\hline & & & $\begin{array}{c}\text { Very Good } \\
(4) \\
\end{array}$ & $\begin{array}{c}\text { Good } \\
\text { (3) }\end{array}$ & $\begin{array}{c}\text { Enough } \\
(2)\end{array}$ & $\begin{array}{c}\text { Less Good } \\
\text { (1) }\end{array}$ \\
\hline & & & $\begin{array}{l}\text { accentuatio } \\
\text { n pattern } \\
(2 / 2, \\
2 / 4,3 / 4,4 / 4), \\
\text { and } \\
\text { compound } \\
\text { bar } \\
(3 / 8,6 / 8,9 / 8, \\
12 / 8)\end{array}$ & $\begin{array}{l}\text { simple } \\
\text { Bar } \\
\text { accentuat } \\
\text { ion } \\
\text { pattern } \\
(2 / 2, \\
2 / 4,3 / 4,4 / \\
4) \text {, and } \\
\text { compound } \\
\text { bar } \\
(3 / 8,6 / 8,9 / \\
8,12 / 8)\end{array}$ & $\begin{array}{l}\text { 2/4,3/4,4/4), and } \\
\text { compound bar } \\
(3 / 8,6 / 8,9 / 8, \\
12 / 8,)\end{array}$ & $\begin{array}{l}\text { 2/4,3/4,4/4), and } \\
\text { compound bar } \\
(3 / 8,6 / 8,9 / 8, \\
12 / 8)\end{array}$ \\
\hline & & $\begin{array}{l}\text { The note } \\
\text { values } \\
\text { Accuracy }\end{array}$ & $\begin{array}{l}\text { Playing / } \\
\text { singing } \\
\text { melodies } \\
\text { consistently } \\
\text { with a } \\
\text { relative note } \\
\text { value }(1, \\
1 / 2,1 / 4,1 / 8, \\
1 / 16.1 / 32 \text {, } \\
\text { triol, } \\
\text { sinkopasi) } \\
\text { written on } \\
\text { sheet music }\end{array}$ & $\begin{array}{l}\text { Playing / } \\
\text { singing } \\
\text { melodies } \\
\text { consistentl } \\
\text { y } \\
\text { with a } \\
\text { relative } \\
\text { note value } \\
(1,1 / 2 \text {, } \\
1 / 4,1 / 8 \text {. } \\
1 / 16 \text {, } \\
1 / 32) \\
\text { written on } \\
\text { sheet } \\
\text { music }\end{array}$ & $\begin{array}{l}\text { Playing / singing } \\
\text { melody is less } \\
\text { consistent } \\
\text { with a relative } \\
\text { note value }(1,1 / 2 \text {, } \\
1 / 4,1 / 8.1 / 16) \\
\text { written on sheet } \\
\text { music }\end{array}$ & $\begin{array}{l}\text { Playing / singing } \\
\text { melody is not } \\
\text { consistent } \\
\text { with a relative } \\
\text { note value }(1,1 / 2 \text {, } \\
1 / 4,1 / 8,1 / 16 \text {. } \\
1 / 32, \text { triol, } \\
\text { sinkopasi) written } \\
\text { on sheet music }\end{array}$ \\
\hline \multirow[t]{2}{*}{2.} & Pitch & $\begin{array}{l}\text { The scale } \\
\text { and pitch } \\
\text { scale } \\
\text { accuracy }\end{array}$ & $\begin{array}{l}\text { Playing / } \\
\text { singing the } \\
\text { melody is in } \\
\text { accordance } \\
\text { to the scale } \\
\text { and pitch } \\
\text { scale } \\
\text { accuracy }\end{array}$ & $\begin{array}{l}\text { Playing } \\
\text { the } \\
\text { melody is } \\
\text { in } \\
\text { accordan } \\
\text { ce with } \\
\text { the scale } \\
\text { accuracy } \\
\text { but not } \\
\text { accordan } \\
\text { ce with } \\
\text { pitch scale }\end{array}$ & $\begin{array}{l}\text { Playing the melody } \\
\text { is not accordance } \\
\text { with the scale } \\
\text { accuracy but in } \\
\text { accordance with } \\
\text { pitch scale }\end{array}$ & $\begin{array}{l}\text { Playing / singing } \\
\text { the melody is not } \\
\text { accordance to the } \\
\text { scale and pitch } \\
\text { scale accuracy }\end{array}$ \\
\hline & & $\begin{array}{l}\text { The melody } \\
\text { accuracy }\end{array}$ & $\begin{array}{l}\text { Playing / } \\
\text { singing } \\
\text { melody is in } \\
\text { each } \\
\text { periods with } \\
\text { antecedents }\end{array}$ & $\begin{array}{l}\text { Playing / } \\
\text { singing a } \\
\text { melody is } \\
\text { in a part } \\
\text { of the } \\
\text { period }\end{array}$ & $\begin{array}{l}\text { Playing / singing } \\
\text { melody is in sub } \\
\text { phrases } \\
\text { incorrectly }\end{array}$ & $\begin{array}{l}\text { Playing a song is } \\
\text { not accordance to } \\
\text { the period, one of } \\
\text { the phrases and } \\
\text { sub-phrases }\end{array}$ \\
\hline
\end{tabular}




\begin{tabular}{|c|c|c|c|c|c|c|}
\hline \multirow[t]{2}{*}{ NO } & \multirow{2}{*}{$\begin{array}{c}\text { Rated } \\
\text { Aspects }\end{array}$} & \multirow[t]{2}{*}{ Indicators } & \multicolumn{4}{|c|}{ SCORE } \\
\hline & & & $\begin{array}{c}\text { Very Good } \\
\text { (4) }\end{array}$ & $\begin{array}{c}\text { Good } \\
(3)\end{array}$ & $\begin{array}{c}\text { Enough } \\
(2)\end{array}$ & $\begin{array}{c}\text { Less Good } \\
\text { (1) }\end{array}$ \\
\hline & & & $\begin{array}{l}\text { and } \\
\text { consequence } \\
\text { s correctly }\end{array}$ & $\begin{array}{l}\text { (one of } \\
\text { the } \\
\text { phrases) } \\
\text { correctly }\end{array}$ & & \\
\hline 3. & Dynamic & $\begin{array}{l}\text { Dynamic } \\
\text { Accuracy }\end{array}$ & $\begin{array}{l}\text { Playing / } \\
\text { singing the } \\
\text { melody is in } \\
\text { accordance } \\
\text { to dynamic } \\
\text { piano signs } \\
\text { and their } \\
\text { derivatives } \\
\text { (p,pp,ppp,pp } \\
\text { pp), forte } \\
\text { and its } \\
\text { derivatives } \\
\text { (f, ff,fff,ffff), } \\
\text { dynamic } \\
\text { graduation } \\
\text { (cresendo, } \\
\text { decresendo) } \\
\text { on sheet } \\
\text { music } \\
\text { consistently }\end{array}$ & $\begin{array}{l}\text { Playing / } \\
\text { singing } \\
\text { the } \\
\text { melody is } \\
\text { in } \\
\text { accordan } \\
\text { ce to } \\
\text { Dynamic } \\
\text { piano } \\
\text { signs and } \\
\text { their } \\
\text { derivative } \\
\text { s } \\
\text { (p,pp,ppp, } \\
\text { pppp), } \\
\text { forte and } \\
\text { its } \\
\text { derivative } \\
\text { s (f, } \\
\text { ff,fff,ffff) } \\
\text { on sheet } \\
\text { music } \\
\text { consistentl } \\
\text { y }\end{array}$ & $\begin{array}{l}\text { Playing / singing } \\
\text { the is melody in } \\
\text { accordance to one } \\
\text { of the Dynamic } \\
\text { signs only }\end{array}$ & $\begin{array}{l}\text { Playing the melody } \\
\text { is not consistent } \\
\text { with the Dynamic } \\
\text { signs written on } \\
\text { sheet music }\end{array}$ \\
\hline \multirow[t]{2}{*}{4} & \multirow[t]{2}{*}{ Timbre } & $\begin{array}{l}\text { Timbre } \\
\text { accuracy in } \\
\text { tone area }\end{array}$ & $\begin{array}{l}\text { Playing / } \\
\text { singing } \\
\text { melodies is } \\
\text { correctly } \\
\text { timbre in all } \\
\text { tone areas }\end{array}$ & $\begin{array}{l}\text { Playing / } \\
\text { singing } \\
\text { melodies } \\
\text { is } \\
\text { correctly } \\
\text { timbre in } \\
\text { certain } \\
\text { tone }\end{array}$ & $\begin{array}{l}\text { Playing / singing } \\
\text { melodies is } \\
\text { correctly timbre } \\
\text { in certain ambitus }\end{array}$ & $\begin{array}{l}\text { Playing / singing } \\
\text { melodies is not } \\
\text { correctly timbre }\end{array}$ \\
\hline & & $\begin{array}{l}\text { Timbre } \\
\text { quality } \\
\text { accuracy }\end{array}$ & $\begin{array}{l}\text { Playing / } \\
\text { singing all } \\
\text { the melodies } \\
\text { is in } \\
\text { accordance } \\
\text { with the } \\
\text { music } \\
\text { timbre }\end{array}$ & $\begin{array}{l}\text { Playing / } \\
\text { singing a } \\
\text { part of the } \\
\text { melodies is } \\
\text { in } \\
\text { accordance } \\
\text { with the } \\
\text { music } \\
\text { timbre }\end{array}$ & $\begin{array}{l}\text { playing / singing a } \\
\text { small portion of } \\
\text { the melody is in } \\
\text { aaccordance to the } \\
\text { music timbre } \\
\text { instrument } \\
\text { consistently }\end{array}$ & $\begin{array}{l}\text { Playing / singing a } \\
\text { melody is not } \\
\text { accordance with } \\
\text { the music timbre } \\
\text { instrument }\end{array}$ \\
\hline
\end{tabular}




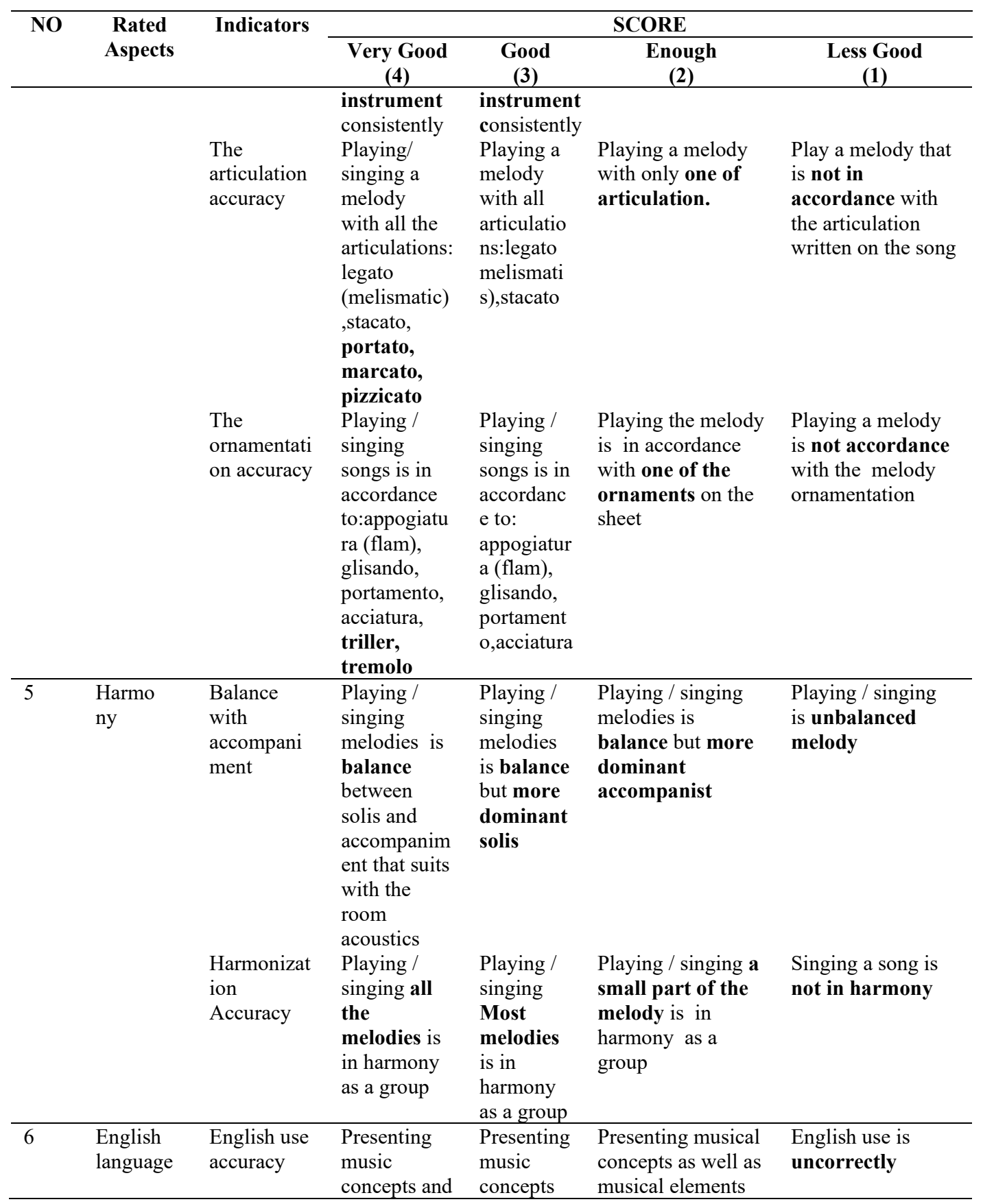




\begin{tabular}{|c|c|c|c|c|c|c|}
\hline \multirow[t]{2}{*}{ NO } & \multirow{2}{*}{$\begin{array}{c}\text { Rated } \\
\text { Aspects }\end{array}$} & \multirow[t]{2}{*}{ Indicators } & \multicolumn{4}{|c|}{ SCORE } \\
\hline & & & $\begin{array}{c}\text { Very Good } \\
\text { (4) }\end{array}$ & $\begin{array}{c}\text { Good } \\
(3)\end{array}$ & $\begin{array}{c}\text { Enough } \\
(2)\end{array}$ & $\begin{array}{c}\text { Less Good } \\
\text { (1) }\end{array}$ \\
\hline & & & $\begin{array}{l}\text { elements of } \\
\text { music in } \\
\text { English } \\
\text { correctly } \\
\text { and } \\
\text { smoothly }\end{array}$ & $\begin{array}{l}\text { and } \\
\text { musical } \\
\text { elements } \\
\text { in English } \\
\text { fluently } \\
\text { and not } \\
\text { yet } \\
\text { correctly }\end{array}$ & $\begin{array}{l}\text { in English } \\
\text { unsmoothly }\end{array}$ & \\
\hline 7 & IT/ICT & $\begin{array}{l}\text { IT/ICT use } \\
\text { accuracy }\end{array}$ & $\begin{array}{l}\text { IT / ICT use } \\
\text { in the artistic } \\
\text { performance } \\
\text { of musical } \\
\text { works is in } \\
\text { accordance } \\
\text { with the } \\
\text { theme of the } \\
\text { musical } \\
\text { work }\end{array}$ & $\begin{array}{l}\text { Most of } \\
\text { the } \\
\text { musical } \\
\text { performa } \\
\text { nce is } \\
\text { using } \\
\text { artistic } \\
\text { instrument } \\
\text { s in } \\
\text { accordanc } \\
\text { e with the } \\
\text { theme of } \\
\text { the music }\end{array}$ & $\begin{array}{l}\text { A small part of } \\
\text { the performance of } \\
\text { musical works is } \\
\text { using artistic in } \\
\text { accordance with } \\
\text { the theme of the } \\
\text { musical work }\end{array}$ & $\begin{array}{l}\text { IT / ICT use is not } \\
\text { in accordance } \\
\text { with the theme of } \\
\text { music }\end{array}$ \\
\hline
\end{tabular}

\section{Conclusion}

The competency assessment must be owned by each study programs to assess the ability of students before graduating from the study program. The competency assessment of Music Education Study Program is called the Presentation of Music Art Work which is conducted individually and in group. Music Education Study Program competency assessment has an assessment standard that can be used by all assessors (lecturers) and examinees (students). The competency assessment is in the form of a musical instrument practice test chosen by students as a major instrument in the Music Education Study Program. In this competency assessment, students will play the last practical material given by the lecturer (semester IV) as the presentation of a single musical work and teach music practice material for the high school students as a presentation of group music.

\section{References}

[1] Kodijat, Latifah. Istilah-istilah Musik, Jakarta: Djambatan (1983).

[2] Banoe, Pono. Kamus Musik, Yogyakarta: Kanisius (2003).

[3] Rien, Syafrina. Pendidikan Seni Musik, Bandung: CV Maulana (2002).

[4] Peter Nickol. Membaca Notasi Musik, Jakarta: PT Gramedia Pustaka Utama (2005).

[5] Wibowo. Manajemen Kinerja, Jakarta Raja Grafindo Parsada (2007). 